\title{
Autoimmunologiczny zespół indukowany przez adiuwanty (ASIA)
}

\section{Autoimmune/inflammatory syndrome induced by adjuvants, ASIA}

\author{
Jędrzej Stolarczyk, Marek Kubiś, Marek Brzosko \\ Klinika Reumatologii, Chorób Wewnętrznych i Geriatrii Pomorskiego Uniwersytetu Medycznego w Szczecinie \\ ul. Unii Lubelskiej 1, 71-252 Szczecin \\ Kierownik: prof. dr hab. n. med. Marek Brzosko
}

\begin{abstract}
There have been many cases of the appearance of autoantibodies and symptoms of disease after exposure to adjuvants, not only after breast augmentation with silicone implants, but also as a very rare vaccination side effect, such as Gulf war syndrome or macrophagic myofasciitis syndrome. Diseases whose symptoms developed after such adjuvant exposure are called autoimmune/ inflammatory syndrome induced by adjuvants (ASIA). The group of adjuvants includes not only silicone implants, silica, squalen and aluminium, but also ink components used for making tattoos. Analyzing the available reports on the influence of adjuvants on the development of autoimmune diseases, the conclusion is that apart from long-term silicone exposure, the coexistence of other factors such as genetic or environmental is also necessary. Metaanalyses clearly do not confirm an increased risk of
\end{abstract}

developing autoimmune disease after breast augmentation with silicone implants, or tattooing, but it seems that among these patients there is a group that is more predestined to develop disease symptoms. In the general population the benefits of vaccination are obvious, and the risk of severe adverse events following immunisation is incomparably lower than the risk of developing a specific disease and its complications, also for patients with diagnosed autoimmune diseases.

Because of data heterogeneity in previous studies and difficulties in diagnosing ASIA it seems necessary to conduct further analyses of adjuvants' influence on autoimmune disease development, and to refine ASIA diagnostic criteria, which now allow too easy a diagnosis of this syndrome.

Keywords: silicone, implant, tattoo, vaccine, immune response, autoimmune diseases.

\section{STRESZCZENIE}

Dotychczas opisano wiele przypadków pojawienia się autoprzeciwciał i objawów chorobowych po ekspozycji na adiuwanty, nie tylko w kontekście wszczepienia silikonowych implantów piersi, ale również jako bardzo rzadko występujące odczyny poszczepienne, zespół wojny w Zatoce Perskiej (Gulf war syndrome) czy zespół makrofagowego zapalenia mięśniowo-powięziowego. Grupę chorób, których objawy wystąpiły po tego typu ekspozycji, nazwano autoimmunologicznym zespołem indukowanym przez adiuwanty (autoimmune/inflammatory syndrome induced by adjuvants - ASIA). Do adiuwantów, oprócz silikonowych implantów, zalicza się krzem, skwalen i glin, a także składniki pigmentów stosowanych do wykonywania tatuaży itp. Analizując piśmiennictwo odnoszące się do wpływu adiuwantów na rozwój chorób autoimmunologicznych, nasuwa się wniosek, że oprócz długotrwałej ekspozycji na silikon konieczne jest również współistnienie innych czynników, takich jak predyspozycja genetyczna czy wpływ czynników środowiskowych. Metaanalizy jednoznacznie nie potwierdzają zwiększenia ryzyka wystąpienia choroby autoimmunologicznej po wszczepieniu silikonowych implantów piersi lub wykonaniu tatuażu, ale możliwe jest zwiększenie predyspozycji do ich wystąpienia w pewnej grupie badanych pacjentów. W populacji ogólnej pozytywny wpływ stosowanych szczepień jest znaczący, a ryzyko wystąpienia poważnych odczynów poszczepiennych jest nieporównywalnie mniejsze niż ryzyko zachorowania na daną jednostkę chorobową i wystąpienia jej powikłań, również u chorych z rozpoznanymi chorobami reumatycznymi.

Ze względu na niejednorodność wyników dotychczasowych badań oraz trudności w diagnostyce i rozpoznawaniu ASIA, konieczne będzie prowadzenie dalszych badań na temat wpływu adiuwantów na rozwój chorób autoimmunologicznych oraz dopracowanie kryteriów ASIA, które pozwalają obecnie na zbyt łatwe rozpoznawanie tego zespołu.

Słowa kluczowe: silikon, implant, tatuaż, szczepienie, odpowiedź immunologiczna, choroby autoimmunologiczne.

\section{WSTĘP}

Dotychczas opisano wiele przypadków pojawienia się objawów chorobowych po ekspozycji na adiuwanty, nie tylko w kontekście wszczepienia silikonowych implantów piersi, ale również jako bardzo rzadko występujące odczyny poszczepienne, zespół wojny w Zatoce Perskiej (Gulf war syndrome) czy zespół makrofagowego zapalenia mięśniowo-powięziowego [1, 2]. Grupę chorób, których objawy wystąpiły po tego typu ekspozycji, nazwano autoimmunologicznym zespołem indukowanym przez adiuwanty (autoimmune/inflammatory syndrome induced by adjuvants - ASIA) [2,3]. Do najczęściej opisywanych chorób, których objawy pojawiły się po zabiegu wszczepienia silikonowych implantów piersi należą: reumatoidalne zapalenie 
stawów (RZS), toczeń rumieniowaty układowy (TRU), twardzina układowa (TU), zespół Sjögrena (ZS), eozynofilowe zapalenie powięzi (EZP), zapalenie wielomięśniowe i zespół przewlekłego zmęczenia $[1,2,3,4,5]$.

Nazwa adiuwant pochodzi od łacińskiego adiuvare, co oznacza pomagać, wzmacniać. Adiuwant to substancja, która niespecyficznie pobudza układ immunologiczny. Dodawana do szczepionek, zwiększa odpowiedź układu immunologicznego wobec właściwego antygenu zawartego w szczepionce, pozwalając tym samym zmniejszyć jego dawkę. Ponadto wydłuża czas ekspozycji ustroju na antygen, przez co zapewnia dłużej trwający efekt szczepienia. Idealny adiuwant nie powinien wywoływać odpowiedzi immunologicznej. Do adiuwantów możemy również zaliczyć m.in.: implanty silikonowe, krzem, skwalen, glin i składniki pigmentów stosowanych do wykonywania tatuaży $[2,5,6]$.

Etiologia chorób autoimmunologicznych nie jest w pełni poznana. Pod uwagę brane są czynniki genetyczne, hormonalne, środowiskowe, ale również przebyte lub przewlekłe infekcje. Zakażenia bakteryjne, wirusowe lub pasożytnicze mogą wywołać zaostrzenie choroby lub pierwszorazowe pojawienie się jej objawów. Prawdopodobnym mechanizmem, dzięki któremu infekcja może być czynnikiem wyzwalającym chorobę autoimmunologiczną, jest zjawisko mimikry molekularnej - podobieństwo antygenów niektórych chorobotwórczych drobnoustrojów do antygenów własnych komórek i tkanek chorego. Oprócz infekcji do wywołania objawów choroby autoimmunologicznej konieczne wydaje się również współwystępowanie innych czynników, takich jak predyspozycja genetyczna lub hormonalna. Wiele patogenów może być odpowiedzialnych za wystąpienie objawów chorób autoimmunologicznych. Do najczęściej wymienianych należą m.in. wirus Epsteina-Barr, wirusy powodujące zapalenie wątroby typu B i C, bakterie Campylobacter jejuni, Streptococcus pyogenes, Klebsiella pneumoniae, Yersinia enterocolitica, a spośród pasożytów zarodźce malarii czy świdrowce z rodziny Leishmania [7].

Od lat 60. XX w., odkąd po raz pierwszy przeprowadzono zabieg wszczepienia silikonowych implantów piersi, nie ustaje dyskusja na temat bezpieczeństwa nie tylko w odniesieniu do powikłań samego zabiegu operacyjnego, znieczulenia oraz gojenia rany, ale również w kontekście występujących po długim czasie reakcji układu immunologicznego - wytworzenia autoprzeciwciał oraz wystąpienia objawów choroby układowej tkanki łącznej [4, 8, 9, 10].

Silikony stanowią dużą, heterogenną grupę syntetycznych polimerów krzemoorganicznych, które są stosowane nie tylko w implantach piersi, ale także w zastawkach komorowo-otrzewnowych, zastawkach serca, soczewkach i wielu innych. Do wypełniania implantów piersi najczęściej używa się silikonu o strukturze chemicznej siloksanu, w której atomy krzemu są połączone mostem tlenowym. Polimery siloksanowe są najbardziej rozpowszechnioną grupą materiałów wśród polimerów krzemoorganicznych. Zmodyfikowane chemicznie, np. poprzez dołączenie odpowiednich podstawników, są wykorzystywane do produkcji m.in. tworzyw sztucznych, materiałów i leków [9, 11].
Krzem, który jest składnikiem silikonu, może powodować różne objawy chorobowe. W przypadku inhalacji pyłu krzemowego może dojść do włóknienia płuc (pylica krzemowa), raka płuc, opłucnej i nosogardła oraz przewlekłej niewydolności nerek [12]. Ponadto u chorych z pylicą krzemową (silicosis) wykazano zwiększone ryzyko rozwoju chorób autoimmunologicznych, takich jak TRU, RZS, stwardnienie rozsiane i zapalenia naczyń $[12,13,14]$. Według Makol i wsp. [14] u tych chorych istnieje zwiększone ryzyko rozwoju zapalenia naczyń.

Cohen Tervaert i Kappel [8] zaproponowali poniższy schemat odpowiedzi układu immunologicznego na silikon. Cząsteczki są wychwytywane przez makrofagi, które ulegają aktywacji i powodują produkcję cytokin prozapalnych, m.in. interleukiny-1. Migracja makrofagów do węzłów chłonnych powoduje nasilenie odpowiedzi zapalnej. Ostatecznie makrofag ulega apoptozie, uwalniając krzem, który jest ponownie wychwytywany przez inne makrofagi. Oprócz tego ekspozycja na cząsteczki zawierające krzem prowadzi do produkcji interleukiny-17, pobudzenia neutrofilów i uwalniania przez nie enzymów, np. mieloperoksydazy. Dochodzi również do odpowiedzi immunologicznej typu II, ze zwiększonym stężeniem IgE, IgG1 i przewlekłej aktywacji limfocytów T, prawdopodobnie z powodu dysfunkcji limfocytów T supresorowych. Nie udało się jednoznacznie określić, czy podobne mechanizmy zachodzą przy ekspozycji na implanty zawierające żel silikonowy, jednak biorąc pod uwagę, że silikonowe polimery mogą ulec oksydacji i uwolnić atomy krzemu, wydaje się to prawdopodobne [8].

Implant piersi składa się z dwóch elementów - zewnętrznej otoczki zbudowanej z wysoko spolimeryzowanych elastomerów wzmocnionych molekułami krzemu (polimery silikonowe) oraz wypełnienia z oleju silikonowego lub soli fizjologicznej. Możliwe jest chirurgiczne umieszczenie implantu podgruczołowo lub podmięśniowo, zależnie od warunków anatomicznych oraz założonego celu zabiegu. Najczęściej występującym powikłaniem miejscowym jest pęknięcie otoczki implantu, które objawia się bólem i znaczną tkliwością piersi [9, 10].

Brinton i wsp. [4] dokonali retrospektywnej analizy porównując grupę kobiet, którym wszczepiono silikonowe implanty piersi z innymi, które przeszły zabieg plastyczny bez wszczepiania silikonowych implantów (np. liposukcję). Autorzy wykazali znacznie większą częstość występowania niektórych chorób autoimmunologicznych u kobiet po wszczepieniu silikonowych implantów piersi. Największy wzrost ryzyka względnego stwierdzono dla ZS (RR = 11,7; 95\% CI: 2,5-54,9), istotnie podwyższone było ono również w przypadku TRU $(\mathrm{RR}=2,1$; 95\% CI: 1,1-4,1), RZS (RR = 1,9; 95\% CI: 1,4-2,7), zespołu przewlekłego zmęczenia (RR $=2,4$; 95\% CI: 1,6-3,6) oraz objawu Raynauda (RR = 2,6; 95\% CI: 1,3-5,1).

Dotychczas przeprowadzono wiele badań oraz opisano przypadki, w których powiązano wystąpienie objawów chorobowych z wszczepieniem silikonowych implantów piersi. Natomiast nie ustalono jednoznacznie ich wpływu na ryzyko względne rozwoju choroby autoimmunologicznej. Do badania kohortowego z 1996 r. Hennekens i wsp. [15] włączyli grupę prawie 12 tys. chorych, u których rozpoznano chorobę autoimmunologiczną (RZS, TRU, TU, ZS, zapalenie wielomięśniowe 
lub skórno-mięśniowe) po zabiegu wszczepienia silikonowych implantów lub które zgłaszały występowanie objawów tych chorób. Obliczono ryzyko względne równe 1,25 (95\% CI: 1,08-1,41). Z kolei Janowsky i wsp. [16] w swojej metaanalizie wprowadzili bardziej restrykcyjne kryteria włączenia do badania. Wymagali potwierdzenia rozpoznania choroby $\mathrm{w}$ dokumentacji medycznej. W ten sposób ustalono ryzyko względne na poziomie 0,80 (95\% CI: 0,62-1,04). Uwzględniając w tej metaanalizie wyniki badań Hennekensa i wsp. [15], można by stwierdzić istotne zwiększenie ryzyka względnego wystąpienia choroby autoimmunologicznej u kobiet po wszczepieniu silikonowych implantów piersi [9]. Wydaje się zatem, że zabieg ten może wywołać objawy chorób autoimmunologicznych, chociaż wyniki przeprowadzonych badań nie są jednoznaczne $[2,9,15,16]$.

Kaiser i wsp. [17] opisali przypadek 42-letniej chorej, u której ok. 10 lat po wszczepieniu silikonowych implantów piersi rozpoznano TRU. Po 6 miesiącach od usunięcia implantów doszło do ustąpienia objawów klinicznych, normalizacji stężeń składowych dopełniacza i parametrów stanu zapalnego oraz zmniejszenia miana przeciwciał przeciwjądrowych (ANA). Wydaje się, że w przypadku wystąpienia objawów układowej choroby tkanki łącznej usunięcie silikonowych implantów nie powstrzymuje progresji choroby, choć opisano przypadek chorej, u której usunięcie implantów pomogło w uzyskaniu remisji [17]. Opisano również przypadki kobiet, u których po wszczepieniu silikonowych implantów piersi wystąpiły sarkoidoza oraz zwłóknienie płuc, którym towarzyszyły niespecyficzne objawy, takie jak bóle stawów, bóle mięśni, gorączka i zmiany skórne [18, 19]. Objawy kliniczne, które mogą występować w postaci powikłań po wszczepieniu silikonowych implantów piersi przedstawiono w tabeli 1.

Badano również obecność autoprzeciwciał po wszczepieniu silikonowych implantów piersi, niezależnie od występowania

TABELA 1. Objawy kliniczne mogące występować jako powikłania po wszczepieniu silikonowych implantów piersi

\begin{tabular}{|c|c|}
\hline Miejscowe & $\begin{array}{l}\text { Zakażenie rany pooperacyjnej. } \\
\text { Ból i tkliwość piersi spowodowana pęknięciem } \\
\text { otoczki implantu. }\end{array}$ \\
\hline & $\begin{array}{l}\text { „Typowa” manifestacja: } \\
\text { - ból, zapalenie lub osłabienie mięśni, } \\
\text { - ból i/lub zapalenie stawów, } \\
\text { - przewlekłe zmęczenie lub zaburzenia snu, } \\
\text { - objawy neurologiczne, } \\
\text { - upośledzenie funkcji poznawczych, zaburzenia } \\
\text { pamięci, } \\
\text { - gorączka, suchość jamy ustnej. }\end{array}$ \\
\hline $\begin{array}{l}\text { Ogólno- } \\
\text { ustrojowe }\end{array}$ & $\begin{array}{l}\text { Objawy chorób autoimmunologicznych: } \\
\text { - reumatoidalne zapalenie stawów, } \\
\text { - toczeń rumieniowaty układowy, } \\
\text { - twardzina układowa, } \\
\text { - zespół Sjögrena, } \\
\text { - eozynofilowe zapalenie powięzi, } \\
\text { - zapalenie wielomięśniowe, } \\
\text { - objaw Raynauda, } \\
\text { - zespół przewlekłego zmęczenia, } \\
\text { - choroba śródmiąższowa i włóknienie płuc, } \\
\text { - sarkoidoza, } \\
\text { - stwardnienie rozsiane, } \\
\text { - zespół Guillaina-Barrégo. }\end{array}$ \\
\hline
\end{tabular}

objawów chorobowych. Porównano grupę 116 kobiet po zabiegu z wszczepieniem silikonowych implantów ze 134 kobietami, u których nie przeprowadzono tego zabiegu. Stwierdzono znacznie częstsze występowanie przeciwciał przeciw topoizomerazie DNA - Scl-70 (RR = 16,2; 95\% CI: 2,2-121,1), rybonukleoproteinie - SS-A/Ro (RR = 10,4; 95\% CI: 1,3-80,8), fosfoproteinie - SS-B/La (RR = 11,6; 95\% CI: 3,6-36,9), rybonukleoproteinom - Sm-RNP (RR = 6,5; 95\% CI: 2,6-16,2) oraz przeciwciał antykardiolipinowych - $\mathrm{aCl}(\mathrm{RR}=3,2 ; 95 \% \mathrm{CI}: 1,5-6,9)$ wśród kobiet z silikonowymi implantami piersi. Wyniki powyższego badania są uznawane za niewystarczające z powodu mało liczebnej grupy badanej, oceny autoprzeciwciał u osób bez objawów chorobowych oraz różnic w budowie wszczepianych implantów (rodzaj wypełnienia, skład otoczki). Na podstawie przedstawionych wyników wydaje się, że ryzyko pojawienia się autoprzeciwciał jest zwiększone wśród kobiet po zabiegu wszczepienia silikonowego implantu piersi [9].

Analizując piśmiennictwo odnoszące się do wpływu adiuwantów na rozwój chorób autoimmunologicznych, nasuwa się wniosek, że oprócz długotrwałej ekspozycji na silikon konieczne jest również współistnienie innych czynników, takich jak predyspozycja genetyczna czy wpływ czynników środowiskowych. Metaanalizy nie potwierdzają jednoznacznie zwiększenia ryzyka wystąpienia choroby autoimmunologicznej wśród kobiet po wszczepieniu silikonowych implantów piersi, jednak wydaje się, że wśród nich będzie grupa bardziej predysponowana do pojawienia się objawów. Przed przystąpieniem do zabiegu estetycznego rolą lekarza powinna być ocena tych czynników ryzyka, jak choćby występowania chorób autoimmunologicznych u osoby kwalifikowanej do zabiegu lub w jej najbliższej rodzinie.

Działania niepożądane, chociaż bardzo rzadko, mogą wystąpić także po szczepieniach. Dokładna liczba odczynów poszczepiennych nie jest znana. Szacunkowo według danych ich występowanie określa się od 1:50 000 do 1:1 000000 dawek, uwzględniając wszystkie, w większości łagodne reakcje. Nie można również jednoznacznie ustalić, który ze składników szczepionki powoduje reakcję immunologiczną, bo oprócz antygenu bakterii lub wirusa może ona zawierać białka lub peptydy zwierzęce (np. białko jaja kurzego), antybiotyki, adiuwanty, konserwanty lub stabilizatory. Objawy mogą być podobne do tych występujących w przebiegu niektórych chorób autoimmunologicznych, jak RZS, TRU, TU, ZS, EZP lub zespół Guillaina-Barrégo [2, 3, 20, 21, 22, 23].

W populacji ogólnej pozytywny wpływ stosowanych szczepień jest znaczący, a ryzyko wystąpienia poważnych odczynów poszczepiennych jest nieporównywalnie mniejsze niż ryzyko zachorowania na daną jednostkę chorobową i wystąpienia jej powikłań. Dlatego wg rekomendacji EULAR należy stosować szczepienia ochronne również u chorych z rozpoznanymi chorobami reumatycznymi, pomimo zwiększonego ryzyka zaostrzenia choroby po szczepieniu, ponieważ nawet dla tych osób konsekwencje przebycia choroby i jej ewentualnych powikłań są groźniejsze, a także bardziej prawdopodobne niż wystąpienie odczynów poszczepiennych.

Chorobą, w której niemal jednoznacznie powiązano objawy kliniczne z wpływem adiuwantów, jest zespół wojny w Zatoce 
Perskiej. Obecne u wielu żołnierzy objawy podobne do występujących w zespole przewlekłego zmęczenia i fibromialgii wynikały prawdopodobnie z autoimmunologicznego zespołu indukowanego przez adiuwanty. Zgłaszali oni występowanie uczucia zmęczenia, bezsenność, zaburzenia koncentracji, gorączkę oraz bóle głowy, stawów i mięśni. Protokół szczepień weteranów zakładał 6-krotne podanie szczepionki przeciwko wąglikowi, w której jako adiuwantów używano skwalenu oraz wodorotlenku glinu. Skwalen jest węglowodorem wielonienasyconym z grupy lipidów, prekursorem cholesterolu, mieliny i niektórych hormonów, występuje naturalnie w ludzkiej skórze oraz tłuszczu z wątroby rekina. Jest używany, podobnie jak wodorotlenek glinu, jako adiuwant w szczepionkach [24, 25]. W wynikach badań wykonanych u ponad 95\% żołnierzy prezentujących objawy $(\mathrm{n}=44)$ stwierdzono obecność przeciwciał przeciwko skwalenowi, których nie stwierdzono u żadnego ze zdrowych żołnierzy z grupy kontrolnej $(n=12)$ [24]. Jednocześnie warto zwrócić uwagę na częstość występowania bólów głowy, depresji oraz zespołu stresu pourazowego (posttraumatic stress disorder - PTSD) wśród weteranów wojennych. W badaniu Carlson i wsp. [26] bóle głowy stwierdzono u 18\% kobiet i 11\% mężczyzn. Często towarzyszyły im inne jednostki chorobowe, takie jak depresja (46\% kobiet i 40\% mężczyzn z bólami głowy), PTSD (38\% kobiet i 58\% mężczyzn z bólami głowy) oraz inne zaburzenia lękowo-depresyjne. Objawy powyższych schorzeń mogą być podobne do występujących w przebiegu zespołu wojny w Zatoce Perskiej, dlatego kluczowym dla rozpoznania tego zespołu powinno być stwierdzenie ekspozycji na adiuwant oraz obecności przeciwciał przeciwko skwalenowi [24, 26].

Zespół makrofagowego zapalenia mięśniowo-powięziowego jest rzadko występującym zespołem chorobowym, w przebiegu którego dochodzi do wytworzenia autoprzeciwciał oraz wystąpienia objawów pod postacią bólu i osłabienia mięśni, zapalenia stawów, gorączki, przewlekłego zmęczenia oraz pogorszenia funkcji poznawczych. Występuje głównie u osób $\mathrm{z}$ antygenem HLA-DR B1*01. W patogenezie zespołu główną rolę najprawdopodobniej odgrywa odkładanie się glinu w mięśniach, który jest stosowany w szczepionce jako adiuwant. Gherardi i wsp. [27] opisali 12 chorych, u których rozpoznano ten zespół [2, 3, 27, 28].

W piśmiennictwie opisano przypadki wystąpienia powikłań po wykonaniu tatuażu na skórze. Wykonanie zabiegu polega na nakłuwaniu skóry w celu wprowadzenia barwnika do tkanki podskórnej. W przypadku niezachowania zasad sterylności możliwe jest lokalne zakażenie skóry, zarażenie wirusami hepatotropowymi lub ludzkim wirusem niedoboru odporności (HIV). Opisane są także reakcje alergiczne, które mają być spowodowane stymulacją układu immunologicznego przez składniki barwników, do których zalicza się m.in. sole metali ciężkich, takich jak chrom, rtęć, tytan czy kadm. Dotychczasowe klasyfikacje przypisywały każdemu kolorowi pigmentu określony metal: czerwony - rtęć, niebieski kobalt, zielony - chrom, fioletowy - magnez. Obecnie wydaje się, że w każdym kolorze pigmentu występuje mieszanina substancji, w tym soli metalicznych, a dotychczasowa klasyfikacja jest uważana za nieaktualną. Część badań była prowadzona pod koniec XX w., a od tamtego czasu wprowadzono bardziej restrykcyjne normy co do zawartości różnych substancji w barwnikach używanych do tatuowania. Określono maksymalne stężenia niektórych soli metalicznych oraz związków organicznych, które są potencjalnie szkodliwe dla organizmu. Mogłoby się wydawać, że obecnie powinno występować mniej działań niepożądanych przy wykonywaniu tatuażu w profesjonalnym gabinecie przy użyciu pigmentów o sprawdzonej zawartości. Do wymienianych działań niepożądanych, których wystąpienie powiązano z tatuażami, należą: zapalenie skóry, pokrzywka, łuszczyca, liszaj płaski, TRU, zapalenie naczyń oraz nadwrażliwość na światło w miejscu tatuażu. Opisano również przypadki nowotworów skóry, takich jak rak podstawnokomórkowy, rak kolczystokomórkowy czy czerniak złośliwy, które rozwijały się na wytatuowanej skórze. Możliwe jest również wystąpienie objawów chorobowych podczas usuwania tatuażu z użyciem lasera, co powoduje uwolnienie pigmentu i możliwość rozpoznania go przez układ odpornościowy jako antygenu oraz co może zapoczątkować reakcję immunologiczną. Sugeruje się, aby przed zabiegiem usuwania tatuażu, w trakcie jego trwania oraz dzień po zastosować doustną profilaktykę glukokortykosteroidami i lekami przeciwhistaminowymi. Nie ustalono dotychczas jednoznacznie jaki jest odsetek powikłań po wykonaniu tatuażu. Dostępne w piśmiennictwie dane na ten temat bazują na opisach pojedynczych przypadków [29, 30, 31, 32].

\section{AUTOIMMUNOLOGICZNY ZESPÓŁ INDUKOWANY PRZEZ ADIUWANTY}

W 2011 r. zaproponowano kryteria rozpoznania ASIA, które przedstawiono w tabeli 2. Autorzy sugerują, że zespół ten można rozpoznać, jeśli chory spełnia dwa duże lub jedno duże i dwa małe kryteria [2,3].

W przypadku podejrzenia choroby wywołanej wszczepieniem silikonowych implantów piersi za typowy obraz histopatologiczny w biopsji można uznać widoczne w barwieniu hematoksyliną i eozyną histiocyty wypełnione złogami silikonu. Trudno mówić o typowym obrazie histopatologicznym w przypadku innych adiuwantów. Kryteria rozpoznania ASIA mogą być zastosowane w diagnostyce różnorodnych zespołów chorobowych, w których kluczową rolę wydają się odgrywać adiuwanty; mają one pomóc lekarzom w analizie trudnych i dotąd niezdiagnozowanych przypadków [2, 3]. W obecnym kształcie wg tych kryteriów zbyt łatwo można rozpoznać ASIA, dlatego też wymagają one dopracowania. Nie zobowiązują lekarza do wykluczenia innych, bardziej prawdopodobnych przyczyn dolegliwości - nowotworu, infekcji lub działania niepożądanego leków. Usystematyzowanie wpływu adiuwantów na rozwój chorób autoimmunologicznych jest istotne, biorąc pod uwagę coraz łatwiejszą dostępność oraz rosnącą popularność zabiegów estetycznych, nie tylko z wszczepieniem silikonowych implantów, ale także innych substancji, jak np. kwasu hialuronowego, toksyny botulinowej lub innych wypełniaczy. 


\begin{tabular}{l|l}
\multicolumn{1}{c|}{ Duże kryteria } & \multicolumn{1}{c}{ Mate kryteria } \\
\hline $\begin{array}{l}\text { 1. Ekspozycja na zewnętrzną stymulację (infekcja, szczepienie, silikon, } \\
\text { inny adiuwant), poprzedzająca wystąpienie objawów klinicznych. }\end{array}$ & $\begin{array}{l}\text { 1. Obecność autoprzeciwciał lub przeciwciał przeciwko } \\
\text { adiuwantowi. }\end{array}$ \\
$\begin{array}{l}\text { 2. Wystąpienie „typowej” manifestacji klinicznej: } \\
\text { - ból, zapalenie lub osłabienie mięśni, }\end{array}$ & $\begin{array}{l}\text { 2. Inne manifestacje kliniczne (np. zespół jelita drażliwego). } \\
\text { - ból i/lub zapalenie stawów, }\end{array}$ \\
- przewlekłe zmęczenie lub zaburzenia snu, & $\begin{array}{l}\text { 4. Ewolucja obrazu w określoną chorobę autoimmunologiczną } \\
\text { (np. stwardnienie rozsiane, twardzina układowa). }\end{array}$ \\
- objawy neurologiczne, & \\
- upośledzenie funkcji poznawczych, zaburzenia pamięci, & \\
- gorączka, suchość jamy ustnej. & \\
3. Usunięcie zewnętrznego czynnika powoduje poprawę stanu klinicznego. & \\
\hline
\end{tabular}

Podobnie moda na tatuaże może przyczynić się do częstszego występowania autoprzeciwciał i objawów chorób autoimmunologicznych w populacji.

Ze względu na niejednorodność wyników dotychczasowych badań oraz trudności w diagnostyce i rozpoznawaniu ASIA konieczne będzie prowadzenie dalszych analiz na temat wpływu adiuwantów na rozwój chorób autoimmunologicznych.

\section{PIŚMIENNICTWO}

1. Agmon-Levin N, Hughes GR, Shoenfeld Y. The spectrum of ASIA: Autoimmune (Auto-inflammatory) Syndrome induced by Adjuvants. Lupus 2012;21(2):118-20.

2. Shoenfeld Y, Agmon-Levin N. ASIA - autoimmune/inflammatory syndrome induced by adjuvants. J Autoimmun 2011;36(1):4-8.

3. Shoenfeld Y, Maślińska M. Autoimmune (auto-inflammatory) syndrome induced by adjuvants - ASIA. Reumatologia 2013;51(2):101-7.

4. Brinton LA, Buckley LM, Dvorkina O, Lubin JH, Colton T, Murray MC, et al. Risk of connective tissue disorders among breast implant patients. Am J Epidemiol 2004;160(7):619-27.

5. Israeli E, Agmon-Levin N, Blank M, Shoenfeld Y. Adjuvants and autoimmunity. Lupus 2009;18(13):1217-25.

6. Balofsky A, Agmon-Levin N, Shoenfeld Y. The new H1N1 and HPV vaccines and old fears. Curr Opin Rheumatol 2010;22(4):431-6.

7. Bach JF. The effect of infections on susceptibility to autoimmune and allergic diseases. N Engl J Med 2002;347(12):911-20.

8. Cohen Tervaert JW, Kappel RM. Silicone implant incompatibility syndrome (SIIS): a frequent cause of ASIA (Shoenfeld's syndrome). Immunol Res 2013;56(2-3):293-8.

9. Hajdu SD, Agmon-Levin N, Shoenfeld Y. Silicone and autoimmunity. Eur J Clin Invest 2011;41(2):203-11.

10. Wolfram D, Oberreiter B, Mayerl C, Soelder E, Ulmer H, Piza-Katzer H. Altered systemic serologic parameters in patients with silicone mammary implants. Immunol Lett 2008;118(1):96-100.

11. Chruściel J, Leśniak E, Fejdyś M. Karbofunkcyjne silany i polisiloksany. Cz. 2, Otrzymywanie i zastosowania karbofunkcyjnych polisiloksanów. Polimery 2008;53(11-12):817-29.

12. Calvert GM, Rice FL, Boiano JM, Sheehy JW, Sanderson WT: Occupational silica exposure and risk of various diseases: an analysis using death certificates from 27 states of the United States. Occup Environ Med 2003;60(2):122-9.

13. Lippmann M, Eckert HL, Hahon N, Morgan WK. Circulating antinuclear and rheumatoid factors in coal miners. A prevalence study in Pennsylvania and West Virginia. Ann Intern Med 1973;79(6):807-11.

14. Makol A, Reilly MJ, Rosenman KD. Prevalence of connective tissue disease in silicosis (1985-2006) - a report from the state of Michigan surveillance system for silicosis. Am J Ind Med 2011;54(4):255-62.
15. Hennekens CH, Lee IM, Cook NR, Hebert PR, Karlson EW, LaMotte F, et al. Self-reported breast implants and connective-tissue diseases in female health professionals. A retrospective cohort study. JAMA 1996;275(8):616-21.

16. Janowsky EC, Kupper LL, Hulka BS. Meta-analyses of the relation between silicone breast implants and the risk of connective-tissue diseases. $\mathrm{N}$ Engl J Med 2000;342(11):781-90.

17. Kaiser W, Biesenbach G, Stuby U, Grafinger P, Zazgornik J. Human adjuvant disease: remission of silicone induced autoimmune disease after explanation of breast augmentation. Ann Rheum Dis 1990;49(11): 937-8.

18. Caldeira M, Ferreira AC. Siliconosis: autoimmune/inflammatory syndrome induced by adjuvants (ASIA). Isr Med Assoc J 2012;14(2):137-8.

19. Pineda JC, Diaz JC, Agualimpia A, Garcia JF. Autoimmune/inflammatory syndrome induced by adjuvants causing myositis and pulmonary fibrosis. Isr Med Assoc J 2013;15(11):720-1.

20. Agmon-Levin N, Paz Z, Israeli E, Shoenfeld Y. Vaccines and autoimmunity. Nat Rev Rheumatol 2009;5(11):648-52.

21. Evans D, Cauchemez S, Hayden FG. "Prepandemic" immunization for novel influenza viruses, "swine flu” vaccine, Guillain-Barré syndrome, and the detection of rare severe adverse events. J Infect Dis 2009;200(3): 321-8.

22. Mikaeloff Y, Caridade G, Suissa S, Tardieu M. Hepatitis B vaccine and the risk of CNS inflammatory demyelination in childhood. Neurology 2009;72(10):873-80.

23. Wood RA, Berger M, Dreskin SC, Setse R, Engler RJ, Dekker CL, et al. An algorithm for treatment of patients with hypersensitivity reactions after vaccines. Pediatrics 2008;122(3):e771-7.

24. Asa PB, Cao Y, Garry RF. Antibodies to squalene in Gulf War syndrome. Exp Mol Pathol 2000;68(1):55-64.

25. Reddy LH, Couvreur P. Squalene: A natural triterpene for use in disease management and therapy. Adv Drug Deliv Rev 2009;61(15):1412-26.

26. Carlson KF, Taylor BC, Hagel EM, Cutting A, Kerns R, Sayer NA. Headache diagnoses among Iraq and Afghanistan war veterans enrolled in VA: a gender comparison. Headache 2013;53(10):1573-82.

27. Gherardi RK, Coquet M, Cherin P, Authier FJ, Laforet P, Belec L, et al. Macrophagic myofasciitis: an emerging entity. Groupe d'Etudes et Recherche sur les Maladies Musculaires Acquises et Dysimmunitaires (GERMMAD) de l'Association Francaise contre les Myopathies (AFM). Lancet 1998;352:347-52.

28. Israeli E. Gulf War syndrome as a part of the autoimmune (autoinflammatory) syndrome induced by adjuvant (ASIA). Lupus 2012;21(2):190-4.

29. Deeken A, Jefferson J, Hawkinson D, Fraga GR. Localized chronic fibrosing vasculitis in a tattoo: a unique adverse tattoo reaction. Am J Dermatopathol 2014;36(4):e81-3.

30. Jolly M, Danila MI. Tattoo: inflicted vasculitis? J Clin Rheumatol 2007;13(1):49.

31. Kazandjieva J, Tsankov N. Tattoos: dermatological complications. Clin Dermatol 2007;25(4):375-82.

32. Kluger N, Koljonen V. Tattoos, inks, and cancer. Lancet Oncol 2012; 13(4):e161-8. 